\title{
Edukasi dan Pelatihan Kewirausahaan Pembuatan Jamu untuk Pemberdayaan Perempuan Desa Langlang Kabupaten Malang
}

\author{
Raisa Fitri $^{{ }^{*}}$, Della Ayu Zona Lia ${ }^{1}$, Filianti ${ }^{1}$, Aniek Murniati ${ }^{2}$ \\ ${ }^{1}$ Jurusan Manajemen, Fakultas Ekonomi \\ Universitas Negeri Malang \\ ${ }^{2}$ Jurusan Akuntansi, Fakultas Ekonomi \\ Institut Teknologi dan Bisnis Asia Malang \\ *Penulis Korespondensi, Raisa Fitri Jurusan Manajemen FE Universitas Negeri Malang, Malang 65145. \\ Email: raisa.fitri.fe@um.ac.id
}

\begin{abstract}
ABSTRAK
Ibu-Ibu di Desa Langlang Kecamatan Singosari Kabupaten Malang banyak yang berstatus sebagai seorang ibu rumah tangga. Mereka biasa mengisi waktu dengan bersosialisasi bersama masyarakat sekitar. Muncul keinginan dari mereka untuk melakukan kegiatan usaha sebagai salah satu cara mengisi waktu luang yang produktif dan menghasilkan materi. Guna mengakomodasi hal tersebut, tim pengabdian kepada masyarakat dari Fakultas Ekonomi Universitas Negeri Malang melaksanakan edukasi dan pelatihan kewirausahaan pembuatan jamu mengingat di Desa Langlang banyak tanaman empon-empon yang belum dimanfaatkan. Metode yang dilakukan adalah: 1) tahap persiapan; 2) tahap pelaksanaan program yang di isi dengan sosialisasi, diskusi, demonstrasi, dan pendmapingan; serta; 3) evaluasi program. Melalui kegiatan ini, ibu-ibu Desa Langlang mendapatkan pengetahuan dan keterampilan di bidang pembuatan jamu, mereka diajari cara memproduksi, mengemas hingga melakukan pemasaran secara offline maupun online. Diharapkan pengetahuan dan keterampilan yang didapatkan mampu terus diimplementasikan oleh ibu-ibu Desa Langlang sehingga terbentuk aktivitas pemberdayaan perempuan yang berkelanjutan guna mendukung pemerintah dalam menciptakan kemajuan ekonomi nasional.
\end{abstract}

Kata Kunci: Desa Langlang, Jamu, Kewirausahaan Tradisional, Pemberdayaan Perempuan

\section{ABSTRACT}

Many women in Langlang Village, Singosari District, Malang Regency have the status of housewives. They usually pass the time by socializing with the surrounding community. There is a desire from them to carry out business activities as a way to fill their free time productively and produce money. In order to accommodate this, the community service team from the Faculty of Economics, Universitas Negeri Malang carried out entrepreneurship education and training in making instant herbal medicine considering that in Langlang Village there are many empon-empon plants that have not been utilized. The methods used are: 1) the preparation stage; 2) the program implementation stage which is filled with socialization, discussion, demonstration, and mentoring; and; 3) program evaluation. Through this activity, Langlang Village women gain knowledge and skills in the field of making instant herbal medicine, they are taught how to produce, package, and do marketing offline and online. It is hoped that the knowledge and skills acquired can continue to be implemented by the women of Langlang Village so that sustainable women's empowerment activities are formed to support the government in creating national economic progress.

Keywords: Langlang Village, Instant Herbal Medicine, Traditional Entrepreneurship, Women Empowerment

PENDAHULUAN

Analisis Situasi
Kegiatan pemberdayaan perempuan merupakan salah satu parameter dalam meningkatkan kesejahteraan di bidang ekonomi 
(Husnaini, Puspasari Heny, 2020). Pemberdayaan perempuan juga mengajarkan pentingnya perempuan untuk memiliki jiwa kemandirian dalam berwirausaha. Perempuan mempunyai peran dalam mengurangi tingkat kemiskinan melalui kegiatan pemberdayaan masyarakat dan kelompok ibu-ibu (Hyunanda et al., 2021). Hal tersebut dimaksudkan untuk mendorong komunitas perempuan agar memiliki kekuatan dan sumber daya guna meningkatkan kualitas hidup keluarga mereka dalam bentuk kegiatan berwirausaha (Utami, 2017). Salah satu buktinya dapat meningkatkan kesejahteraan keluarganya dengan melakukan kegiatan usaha produktif rumah tangga. Kemudian secara bertahap hal tersebut akan berdampak kepada perubahan nilai-nilai sosial, pendidikan, budaya dan politik. Kesejahteraan kaum perempuan akan berdampak pada kesejahteraan semua aspek dalam kehidupan (Andrew, 1984; Jensen, 2017).

Desa Langlang Kecamatan Singosari Kabupaten Malang merupakan sebuah daerah yang berada di wilayah lereng Gunung Arjuno. Kondisi tanahnya cukup subur dan sangat mendukung untuk ditanami berbagai jenis tanaman. Masyarakat perempuan Desa Langlang banyak yang berprofesi sebagai ibu rumah tangga. Berdasarkan hasil observasi yang dilakukan oleh tim pengabdian, ibu-ibu Desa Langlang sangat tertarik untuk memiliki usaha dibuktikan dengan beberapa ibu-ibu yang mulai merintis usaha kecil. Akan tetapi, sebagian besar ibu-ibu kurang memiliki pengetahuan dan ketarmpilan yang dapat dijadikan bekal merintis sebuah usaha.

Ketersediaan lahan di Desa Langlang cukup luas. Meskipun di beberapa wilayah banyak dipadati oleh bangunan rumah warga, akan tetapi juga masih banyak lahan yang digunakan bertani. Di sekitar rumah warga juga terdapat lahan kosong dan biasanya ditanami bunga serta empon-empon. Bunga sebagai pengindah suasana rumah warga dan empon-empon sebagai salah satu persediaan bumbu dapur dalam skala kecil. Suburnya tanah Desa Langlang mengakibatkan tumbuhan empon-empon yang ditanam subur hingga persediaannya melebihi kebutuhan dapur warga. Hal ini pun memberikan peluang agar tumbuhan emponempon dimanfaatkan untuk tujuan lain.

Setelah tim pengabdian melakukan diskusi lebih lanjut dengan beberapa perwakilan ibu-ibu Desa Langlang, mereka sangat ingin memanfaatkan tumbuhan empon-empon sebagai bahan bisnis. Di sisi lain juga ditemui fakta bahwa bahan dasar utama pembuatan jamu banyak ditemui di sekitar lingkungan rumah bahkan di setiap rumah banyak ditemui tanaman empon-empon seperti serai, jahe, kunyit, dan temulawak. Akan tetapi selama ini masyarakat sekitar belum terlalu menyadari akan manfaat yang dihasilkan. Belum optimalnya kegunaan tanaman empon-empon tersebut menjadi jamu serbuk instan karena kurangnya pengetahuan dan keterampilan masyarakat dalam hal pembuatan jamu yang memiliki nilai ekonomis apabila dijual.

Hal inilah yang memunculkan ide agar dilakukan kegiatan edukasi dan pelatihan kewirausahaan produksi jamu bagi ibu-ibu Desa Langlang. Adanya lahan yang masih kosong, nantinya dapat dimanfaatkan sebagai kebun tumbuhan empon-empon, agar ketersediaan bahan produksi bisa tetap melimpah. Edukasi dan pelatihan pembuatan jamu untuk ibu-ibu seperti ini telah terbukti efektif memberdayakan perempuan di wilayah pedesaan (Ismono et al., 2018; Wahyuningsih and Widiyastuti, 2019). Guna menghasilkan output yang maksimal, nantinya ibu-ibu Desa Langlang yang tergabung juga akan didampingi selama beberapa bulan oleh tim pengabdian (Iswati et al., 2017).

Melalui kegiatan pendampingan kewirausahaan pembuatan jamu, dengan bahan yang mudah didapatkan, dan tidak memakan waktu yang lama diharapkan mampu menjadi salah satu cara efektif untuk memberdayakan ibu-ibu Desa Langlang, terutama yang berprofesi sebagai ibu rumah tangga. Bahkan salah satu keunggulannya adalah khasiat jamu bagus untuk menambah imunitas tubuh (Kusumo et al., 2020). Bahan dasar utama dalam pembuatan jamu mudah diperoleh karena 
berasal dari jenis tanaman lokal seperti temulawak, jahe dan kunyit yang dikenal dengan tanaman empon-empon (Sastrawidana, 2020). Proses pembuatan jamu juga cukup sederhana tidak terlalu rumit. Maka hal ini sangat cocok menjadi pilihan ibu-ibu untuk belajar keterlampilan pembuatan jamu dan dapat menjadi pilihan berwirausaha.

\section{Tujuan dan Manfaat Kegiatan}

Program pengabdian kepada masyarakat ini bertujuan untuk memberikan pengetahuan dan keterampilan yang dapat dijadikan bekal merintis usaha guna meingkatkan kemandirian berwirausaha pada ibu-ibu di Desa Langlang. Kegiatan ini juga memperhatikan bagaimana cara pengemasan jamu yang menarik agar siap dijual di pasaran. Selain itu, pelatihan terkait pemasaran secar offline dan online juga disampaikan. Pemasaran offline dapat dilakukan dengan menitipkan produk ke toko-toko di sekitar Desa Langlang, sedangkan pemasaran online dapat dilakukan melalui berbagai media sosial dan online marketplace.

Harapannya dengan kemandirian berwirausaha, mampu meningkatkan nilai ekonomi keluarga ibu-ibu Desa Langlang yang nantinya dapat dikembangkan menjadi usaha kecil dan menengah di bidang obat-obatan herbal seperti jamu serbuk instan, yang selanjutnya dapat disalurkan ke masyarakat luas. Pendampingan ini memberikan kesempatan kepada ibu-ibu agar tetap bisa menjalankan peran utamanya sebaga ibu rumah tangga karena pembuatan jamu ini bisa dilakukan di rumah masing-masing. Peluang pemasaran produk jamu juga terbuka lebar, apalagi di saat pandemi seperti ini dimana jamu yang berasal dari tanaman empon-empon sangat diminati. Secara farmakologis, tanaman empon-empon selain untuk menambah nafsu makan juga berkhasiat menjaga imunitas tubuh dan dapat mengatasi berbagai macam jenis penyakit (Elfahmi et al., 2014).

Manfaat kegiatan pengabdian kepada masyarakat ini akan dirasakan secara bertahap. Pertama, manfaat akan dirasakan oleh ibu-ibu
Desa Langlang selaku sasaran utama kegiatan ini. Jika pengetahuan dan keterampilan yang disampaikan dapat diimplementasikan secara baik oleh peserta dan tim pengabdian dapat terus melakukan kegiatan pendampingan, maka manfaat akan terasa bagi pemerintah desa setempat. Hal ini dikarenakan secara tidak langsung warga Desa Langlang akan lebih produktif. Sehingga kualitas masyarakatnya dapat meningkat. Manfaat selanjutnya dapat dirasakan oleh pemerintah yang lebih luas yakni seperti pemerintah di Kecamatan Singosari Kabupaten Malang, dan seterusnya.

\section{METODE PELAKSANAAN}

\section{Sasaran kegiatan}

Program pengabdian ini melibatkan tiga pihak utama dalam menyukseskan kegiatan yaitu: ibu-ibu desa, pemerintah desa, dan pihak Universitas Negeri Malang. Pola pengumpulan peserta adalah tim pelaksana pengabdian bekerja sama dengan perangkat desa untuk mengumpulkan ibu-ibu di Desa Langlang Kecamatan Singosari Kabupaten Malang yang berjumlah 20 orang. Latar belakang pendidikan ibu-ibu di Desa Langlang mayoritas berpendidikan sampai tingkat SLTA dan sebagaian besar adalah ibu rumah tangga.

\section{Lokasi kegiatan}

Pelaksanaan kegiatan pengabdian kepada masyarakat ini bertempat di salah satu rumah warga yang berlokasi di Dusun Langlang 1 Desa Langlang Kecamatan Singosari Kabupaten Malang. Pelaksanaan kegiatan ini dengan menerapkan protokol kesehatan selama pandemi covid-19. Kegiatan edukasi dan pelatihan diadakan pada bulan Juli 2021 dan selanjutnya dilakukan pendampingan selama kurang lebih tiga bulan.

\section{Metode yang digunakan :}

Program pelatihan dan pendampingan fokus pada "pemberdayaan perempuan untuk meningkatkan kemandirian berwirausaha pembuatan jamu di Desa Langlang Kabupaten 
Malang”. Adapun program yang dilakukan adalah sebagai berikut:

1. Tahap Persiapan, yang terdiri dari langkah-langkah berikut: a) Identifikasi kebutuhan pelaksanaan program pengabdian masyarakat; b) Koordinasi dengan perangkat desa; c) Mengundang ibu-ibu sebagai peserta pelatihan yang memiliki semangat tinggi untuk berwirausaha atau ibu-ibu yang sudah memiliki usaha; dan d) Pendataan peserta pelatihan seperti nama, usia, dan jenis produk lokal yang diproduksi agar menjadi salah satu database tim pelaksana.

2. Tahap Pelaksanaan Program, yang terdiri dari langkah-langkah berikut: a) Sosialisasi dan pemberian pengetahuan dan pemahaman mengenai pentingnya kemandirian berwirausaha dan peluang usaha rumahan untuk menarik minat dan motivasi dalam berwirausaha kepada ibu-ibu; b) Sharing session terkait kendala mitra untuk merintis usaha; dan c) Program pendampingan pembuatan jamu pada ibu-ibu di Desa Langlang yang terdiri dari pelatihan dan pendampingan cara pembuatan jamu dari tanaman tanaman empon-empon (jahe, temulawak dan kunyit). Pelatihan tersebut disampikan dalam bentuk ceramah yang dilanjutkan dengan eksperimen langsung dengan ibu-ibu. Pelatihan dilaksanakan sampai semua peserta mahir mempratikkan sendiri sehingga menuntut proses pendampingan tidak cukup hanya satu kali saja, yakni dilakukan sebanyak tiga kali.

3. Tahap Evaluasi Program, yang terdiri dari langkah-langkah berikut: a) Mencatat permasalahan-permasalahan yang muncul selama proses pelatihan; b) Melakukan evaluasi. Kriteria evaluasi meliputi kesadaran dan antusiasme peserta pelatihan dalam mengikuti kegiatan serta tingkat kemahiran peserta dalam mempratikkan sendiri cara pembuatan jamu yang telah diajarkan, baik itu umpan balik dan respon dari peserta; c) Membuat notulensi pelaksanaan kegiatan.

\section{HASIL DAN PEMBAHASAN}

Tujuan kegiatan pengabdian kepada masyarakat ini adalah untuk memberikan pengetahuan dan keterampilan yang dapat dijadikan bekal merintis usaha produksi jamu guna meingkatkan kemandirian berwirausaha pada ibu-ibu di Desa Langlang Kecamatan Singosari Kabupaten Malang. Kegiatan terlaksana melalui tiga tahapan, berikut merupakan penjelasan dari setiap tahapan yang telah dim pengabdian lakukan.

\section{Tahap Persiapan}

Di tahap persiapan ini, tim pengabdian melakukan observasi secara langsung dan tidak langsung ke Desa Langlang. Hal ini untuk mengidentifikasi permasalahan yang ada dan peluang apa saja yang dimungkinkan dapat menjadi solusi. Di tahap ini pula tim pengabdian melakukan penyiapan materi edukasi dan pelatihan. Di sisi lain juga membuat desain produk untuk kemasan jamu. Terdapat tiga jenis kemasan yang disiapkan oleh tim pengabdian, yakni kemasan botol $200 \mathrm{ml}$ dan $350 \mathrm{ml}$ serta kemasan plastik. Berikut di Gambar 1 merupakan desain yang telah dibuat oleh tim pengabdian.

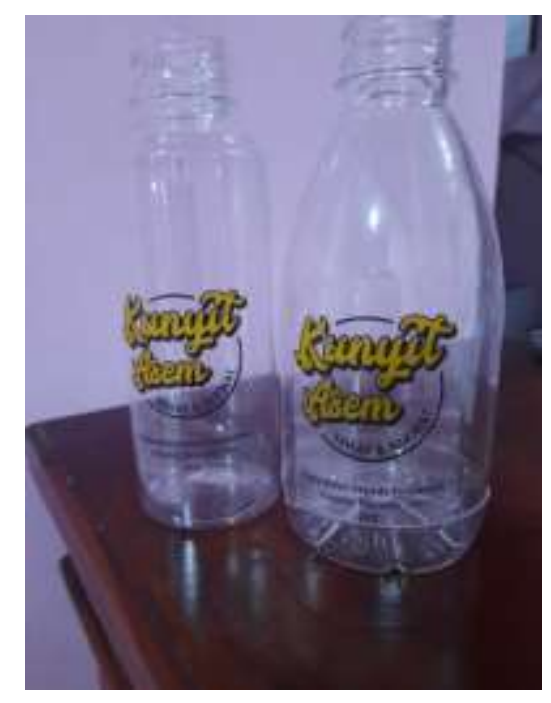

Gambar 1. Desain Produk Jamu Ibu-ibu Desa Langlang

Di tahap persiapan juga dilakukan proses koordinasi lebih lanjut dengan pemerintah desa setempat. Tim pengabdian diberikan akses melalui ibu kepala desa dan ketua PKK untuk 
mengundang ibu-ibu Desa Langlang dalam kegiatan yang dilaksanakan pada bulan Juli 2021. Terdapat sekitar dua puluh ibu-ibu yang diundang, mayoritas dari mereka berprofesi sebagai ibu rumah tangga.

\section{Tahap Pelaksanaan Program}

Di tahap pelaksanaan program dilakukan kegiatan edukasi dan pelatihan yang bertempat di salah satu rumah warga. Mulanya tim pengabdian membuka acara dan memberikan kesempatan pada perwakilan Desa Langlang untuk memberi sambutan. Setelah itu dilakukan pemberian materi seputar manfaat jamu untuk kesehatan masyarakat, peluang bisnis di bidang pembuatan jamu, kemudahan dan tantangan dalam melakukan bisnis jamu, tata cara proses produksi jamu, dan materi lain yang relevan dengan topik kegiatan. Materi disampaikan oleh Raisa Fitri, S.AB., M.M. yang didampingi oleh dosen dari Fakultas Ekonomi Universitas lainnya, yakni Della Ayu Zonna Lia, S.AB., M.AB. Berikut di Gambar 2 merupakan potret saat dipaparkan materi.

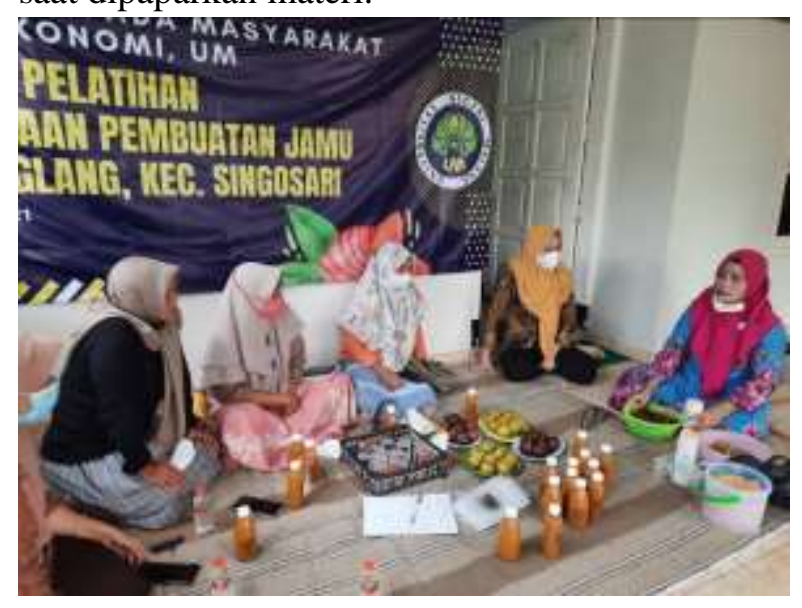

Gambar 2. Kegiatan Pemaparan Materi

Saat dilakukan pemaparan materi, peserta terlihat sangat antusias. Hal ini dapat dilihat dari fokusnya mereka menyimak materi yang disampaikan dan aktif dalam proses tanyajawab. Hal ini pun dilanjutkan dengan kegiatan sharing untuk mengetahui penerimaan peserta terhadap materi yang disampaikan, khususnya implementasinya dalam kondisi riil di lapangan. Beberapa peserta tidak mengalami kendala yang berarti selain mereka masih bingung dalam hal proses pengemasan produk yang tahan lama. Melalui kendala ini pun tim pengabdian menawarkan agar digunakan jenis pengamasan vakum maupun produksi jamu untuk penjualan harian.

Saat sharing, peserta juga banyak bertanya terkait tips dan trik dalam melakukan kegiatan wirausaha, terutama di masa pandemi covid-19 dimana aktivitas masyarakat di luar rumah sangatlah dibatasi. Tim pengabdian pun merekomendasikan agar dimaksimalkan pemasaran online, mengingat saat ini hampir seluruh masyarakat juga sudah memiliki gawai pintar. Ibu-ibu Desa Langlang dapat memaksimalkan WhatsApp Story yang kini juga sangat digandrungi masyarakat desa. Berikut di Gambar 3 merupakan potret saat sesi sharing dilakukan.

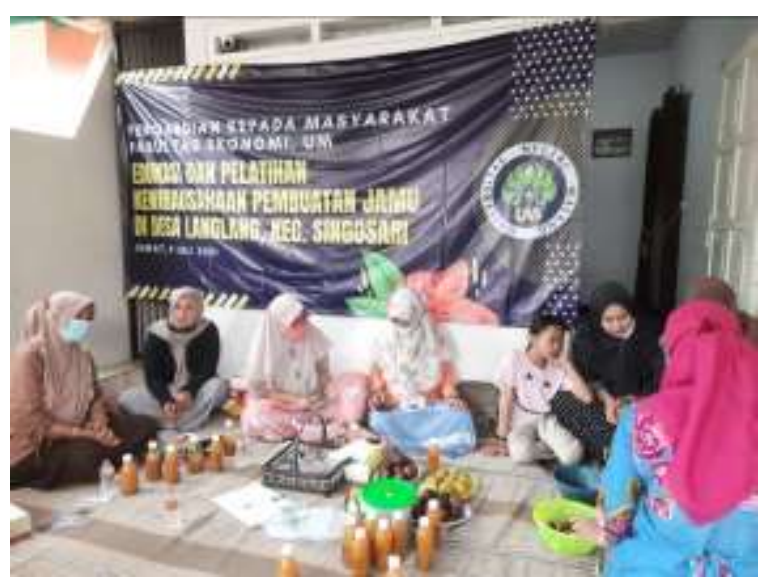

Gambar 3. Sesi Sharing Antara Tim Pengabdian dan Peserta

Setelah hampir semua kendala dan pertanyaan peserta dapat diatasi oleh tim pengabdian, tahap selanjutnya adalah dilakukan praktik pembuatan jamu secara langsung oleh tim pengabdian. Mulanya praktik diawali dengan memotong bahan berupa jahe merah, kencur dan beberapa bahan lain. Kemudian bahan-bahan tersebut dihaluskan dengan menggunakan blender. Setelah itu bahan dimasak dengan ditambahkan bahan tambahan lain yakni gula dan air hingga menjadi kristal. Setelah menjadi kristal dilakukan pemrosesan agar bahan yang telah matang menjadi butiran 
layaknya tepung. Proses praktik secara langsung ini akan membuat peserta tergambar sekaligus termotivasi dalam membuat produk jamu (Sastrawidana, 2020). Di Gambar 4 berikut merupakan beberapa dokumentasi saat dilakukan proses produksi langsung oleh tim pengabdian saat dilaksanakannya acara.

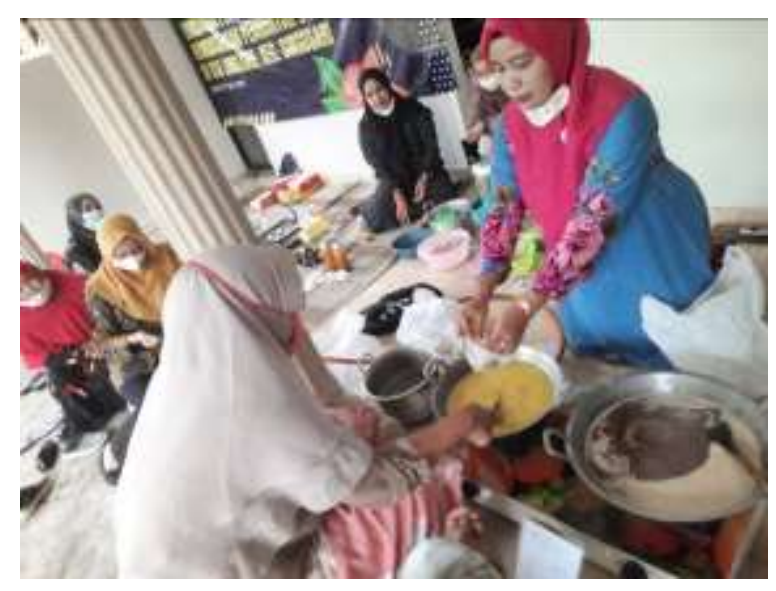

Gambar 4. Kegiatan Praktik Langsung Pembuatan Jamu oleh Tim Pengabdian

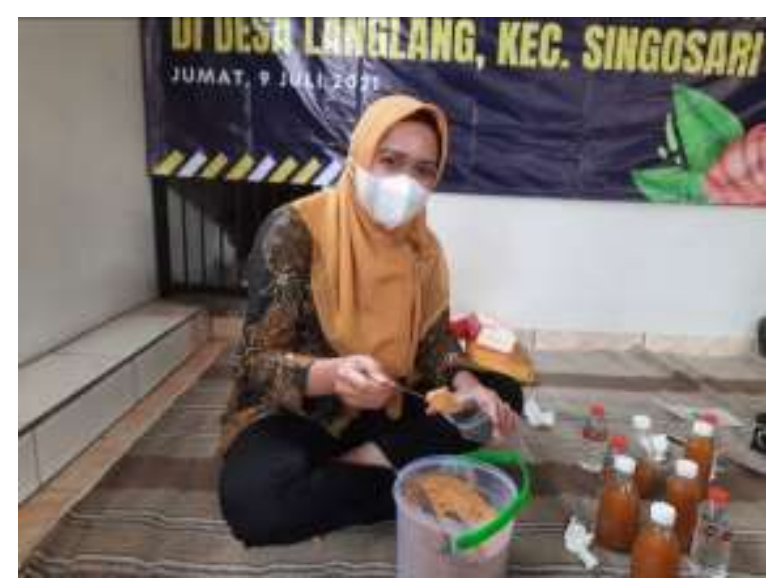

Gambar 5. Proses Pengemasan Produk

Saat dilakukan praktik secara langsung, peserta menyimak dengan baik dan kemudian mereka turut serta dalam proses praktik tersebut. Hal ini akan semakin meningkatkan keterampilan dan motivasi peserta dalam hal produksi jamu. Di akhir acara, peserta juga kembali melakukan praktik secara mandiri untuk memastikan bahwa mereka sudah siap untuk melakukan kegiatan wirausaha pembuatan jamu. Berikut pada Gambar 6 merupakan dokumentasi hasil jamu yang telah diproduksi saat acara.

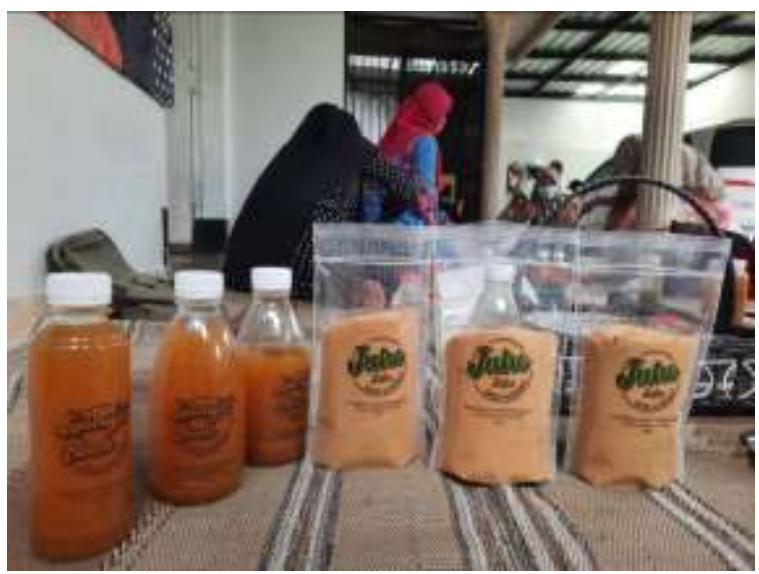

Gambar 6. Hasil Produk Jamu yang Telah Diproduksi.

Setelah dilakukan serangkaian tahapan pelaksanaan program, selanjutnya peserta akan didampingi secara intensif oleh tim pengabdian dalam melakukan wirausaha ini. Proses pendampingan dilakukan secara virtual, mengingat di Malang Raya masih terjadi pandemi covid-19 sehingga mobilitas ke luar rumah harus benar-benar dibatasi. Peserta dapat kapan saja berkonsultasi dengan tim pengabdian melalui pesan WhatsApp maupun video call di Google Meet jika dibutuhkan koordinasi secara mendesak. Proses pendampingan ini dilakukan selama kurang lebih tiga bulan untuk mencapai hasil transfer pengetahuan dan keterampilan yang berkualitas.

\section{Tahap Evaluasi Program}

Evaluasi program penting dilakukan guna mengukur ketercapain tujuan pengabdian kepada masyarakat yang sebelumnya telah ditetapkan. Tim pengabdian melakukan wawancara baik tepat saat kegiatan edukasi dan pelatihan selesai dilaksanakan, serta saat proses pendampingan. Hal ini untuk mengetahui hal apa saja yang menjadi kendala kegitan serta tujuan-tujuan apa saja yang masih belum tercapai. Selanjutnya berdasarkan evaluasi program yang didapatkan, tim pengabdian memberikan solusi-solusi untuk dilaksanakan.

Saat ini eksistensi jamu, terutama yang diolah dari bahan-bahan alami tanpa ada tambahan bahan kimia sama sekali sangatlah diminati. Hal ini terjadi sudah sejak beberapa 
tahun terakhir (Setyowati et al., 2017), bahkan di saat terjadi pandemi covid-19 seperti tahun 2020 dan 2021 ini, permintan pasar semakin tinggi. Meskipun jamu tidak dapat menyembuhkan pasien covid-19, akan tetapi konsumsinya dapat menambah imunitas tubuh sehingga dapat menghindarkan masyarakat dari terpapar virus ini. Namun harus dicatat, pelaksanaan protokol kesehatan haruslah tetap dilakukan secara maksimal oleh masyarakat.

Produksi jamu yang dibarengi dengan pemanfaatan teknologi tepat guna seperti yang pernah dilakukan oleh Muttaqin et al., (2015) saat membina pegiat usaha jamu di Jawa Tengah terbukti mampu meningkatkan kualitas produksi, kuantitas produksi, dan peningkatan manajemen usaha. Seiring dengan adanya modernitas zaman dan kemajuan teknologi, kegiatan usaha jamu dalam bentuk cair maupun serbuk juga harus dibarengi dengan peningkatan kualitas pengemasan produk. Seperit yang disampaikan oleh Mugniza et al., (2020) dalam hasil penelitiannya, upaya perancangan identitas merek minuman jamu tradisional dapat meningkatkan minat masyarakat kota dalam mengonsumsinya. Seperti yang diketahui, saat ini minat mengonsumsi jamu masih cukup terbatas bagi masyarakat yang tinggal di pedesaan.

Jamu yang telah diproduksi harus dipasarkan dengan metode yang tepat dan menyesuaikan karakteristik target pasar saat ini. Pemasaran produk dapat dilakukan secara offline maupun online agar jamu dapat terjual secara maksimal. Saat ini hampir masyarakat tidak peduli di desa maupun di kota sangat menggemari aktivitas berbelanja online, terlebih di era pandemi covid-19 (Koch et al., 2020). Ibu-ibu pelaku usaha produksi jamu di Desa Langlang pun harus melakukannya. Hal ini dapat dilakukan dengan cara menjual produk melalui media sosial Facebook, Instagram dan WhatsApp Story. Pemanfaatan berbagai online marketplace juga harus dimaksimalkan untuk menjual produk jamu.

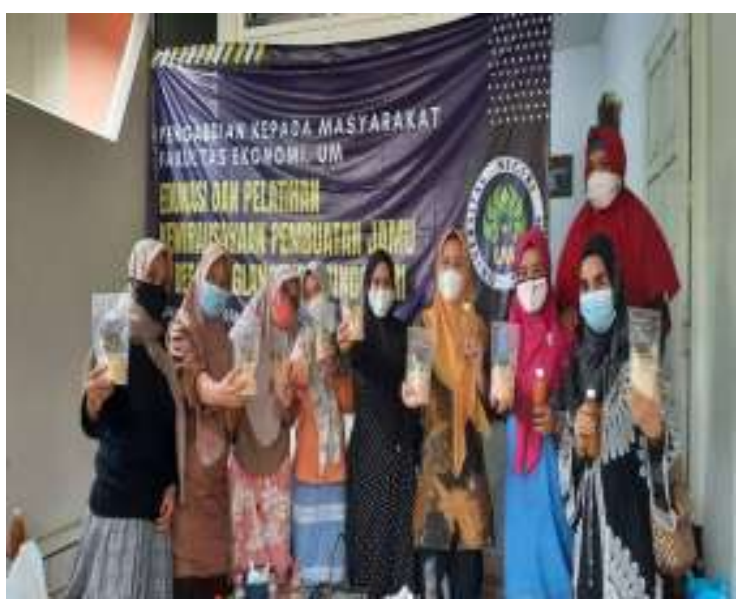

Gambar 7. Dokumentasi Foto Bersama antara Peserta dan Tim Pengabdian

Keberadaan jamu yang notabene merupakan kelompok minuman dan obat-obatan tradisional Indonesia kini keberadaannya tidak dapat dianggap remeh. Masyarakat dapat memanfaatkan peluang produksi jamu dengan baik, terutama ibu-ibu Desa Langlang yang telah mendapatkan edukasi dan pelatihan mulai dari proses produksi, pengemasan produk hingga pemasaran produk. Melalui hal ini tentu akan berdampak pada kesejahteraan sosial masyarakat, terutama dalam hal pemberdayaan perempuan di desa setempat.

\section{KESIMPULAN DAN SARAN}

Melalui pelaksanaan kegiatan pengabdian kepada masyarakat dalam bentuk edukasi dan pelatihan kewirausahaan pembuatan jamu yang telah dilakukan, ibu-ibu Desa Langlang Kecamatan Singosari Kabupaten Malang kini telah memiliki pengetahuan dan keterampilan di bidang tersebut. Bentuk pengetahuan dan keterampilan yang dimiliki mencakup proses produksi jamu, baik dalam bentuk cair maupun serbuk, proses pengemasan dan desain produk yang menarik hingga proses pemasaran baik secara offline maupun online. Kegiatan usaha pembuatan jamu ini dapat dilakukan secara individu maupun kelompok melalui bimbingan pemerintah desa setempat. Melalui kegiatan usaha ini pula ibu-ibu Desa Langlang dapat memanfaatkan waktu luangnya menjadi kegiatan yang produktif dan menghasilkan materi, 
sehingga dapat meningkatkan kesejahteraan keluarganya.

Diharapkan pengetahuan dan keterampilan yang telah diberikan dapat terus diimplementasikan oleh ibu-ibu Desa Langlang dalam melakukan kegiatan usaha. Hal ini agar usaha pembuatan jamu yang dilakukan dapat mendatangkan keuntungan yang lebih besar. Bahkan jika perlu pemerintah desa setempat harus turun tangan memberikan dukungan baik moril maupun non-moril agar keberadaan kegiatan usaha jamu menjadi salah satu identitas yang dimiliki oleh Desa Langlang sebagai salah satu desa yang masuk ke dalam zona KEK (Kawasan Ekonomi Khusus).

\section{UCAPAN TERIMAKASIH}

Tim Pengabdian kepada Masyarakat mengucapkan terima kasih kepada Fakultas Ekonmi, Universitas Negeri Malang atas didanainya kegiatan ini dalam bentuk skema Hibah Dana PNBP Fakultas Ekonomi Universitas Negeri Malang Tahun 2021. Tim ini juga mengucapkan terima kasih kepada perangkat desa serta ibu-ibu PKK Desa Langlang Kecamatan Singosari Kabupaten Malang atas diberikannya kesempatan untuk mengadakan kegiatan Pengabdian kepada Masyarakt di tempat tersebut.

\section{DAFTAR RUJUKAN}

Andrew, C., 1984. Women and the Welfare State. Can. J. Polit. Sci. Rev. Can. Sci. Polit. 17, 667-683.

Elfahmi, Woerdenbag, H.J., Kayser, O., 2014. Jamu: Indonesian traditional herbal medicine towards rational phytopharmacological use. J. Herb. Med. 4, 51-73. https://doi.org/10.1016/j.hermed.2014.0 1.002

Husnaini, Puspasari Heny, W.W., 2020. Pelatihan Pembuatan Jamu Berbasis Home Industry Kader Puskesmas Perumnas 2 di Kelurahan Sei Beliung Kota Pontianak 2, 44-45. https://doi.org/10.1201/978131527450820

Hyunanda, V.F., Palacios Ramírez, J., LópezMartínez, G., Meseguer-Sánchez, V.,
2021. State Ibuism and Women's Empowerment in Indonesia: Governmentality and Political Subjectification of Chinese Benteng Women. Sustainability 13, 3559. https://doi.org/10.3390/su13063559

Ismono, I., Suyatno, S., Hidajati, N., 2018. PELATIHAN PEMBUATAN SERBUK MINUMAN HERBAL INSTAN UNTUK WARGA DESA JAJAR, KECAMATAN TALUN, KABUPATEN BLITAR. J. ABDI Media Pengabdi. Kpd. Masy. 3, 76-83. https://doi.org/10.26740/ja.v3n2.p76-83

Iswati, S., Purwanto, D.A., Iswajuni, I., 2017. PENGEMBANGAN PRODUK JAHE MERAH INSTANT DENGAN TECHNOLOGY SPRAY DRYING DI KAB. BANYUWANGI UNTUK KUALITAS EKSPOR. J. Layanan Masy. J. Public Serv. 1, 83-88. https://doi.org/10.20473/jlm.v1i2.2017.8 3-88

Jensen, P.H., 2017. Cause and effects of female labour force participation in local welfare systems. Eur. Soc. 19, 121-137. https://doi.org/10.1080/14616696.2016. 1268706

Koch, J., Frommeyer, B., Schewe, G., 2020. Online Shopping Motives during the COVID-19 Pandemic-Lessons from the Crisis. Sustainability 12, 10247. https://doi.org/10.3390/su122410247

Kusumo, A.R., Wiyoga, F.Y., Perdana, H.P., Khairunnisa, I., Suhandi, R.I., Prastika, S.S., 2020. JAMU TRADISIONAL INDONESIA: TINGKATKAN IMUNITAS TUBUH SECARA ALAMI SELAMA PANDEMI. J. Layanan Masy. J. Public Serv. 4, 465. https://doi.org/10.20473/jlm.v4i2.2020.4 65-471

Mugniza, N., Sulistianto, N., Siswanto, R.A., 2020. Perancangan Identitas Minuman Tradisional Minuman Jamu Gendong Untuk Meningkatkan Daya Minat Konsumen. EProceedings Art Des. 7.

Muttaqin, H., Cahyadin, M., Widiyanti, E., 2015. PEMBERDAYAAN USAHA JAMU JAHE INSTAN DI KOTA SURAKARTA DAN KABUPATEN SUKOHARJO MELALUI TEKNOLOGI PENGOLAHAN JAHE. INOTEKS 19, 124-138. 
Sastrawidana, I.D.K., 2020. Edukasi Dan Pelatihan Pembuatan Jamu Serbuk Temujaku (Temulawak-Jahe-Kunyit) Kepada Kelompok Pkk Desa Baktiseraga 7-13.

Setyowati, N., Fajarningsih, R.U., Adi, R.K., 2017. ANALISIS POTENSI DAN STRATEGI PENGEMBANGAN JAMU DI KABUPATEN KARANGANYAR. Caraka Tani J. Sustain. Agric. 27, 63-74. https://doi.org/10.20961/carakatani.v27i 1.14356

Utami, F., 2017. Pemberdayaan Perempuan di Kelompok Batik Giriwangi Desa Kebondalem Kidul Prambanan. Вестник Росздравнадзора 6, 5-9.

Wahyuningsih, I., Widiyastuti, L., 2019. Pengolahan Empon-Empon Menjadi Minuman Kesehatan Berbasis Zero Waste Home Industry. Berdikari J. Inov. Dan Penerapan Ipteks 7, 53-61. https://doi.org/10.18196/bdr.7157 